Sains Malaysiana 50(4)(2021): 1089-1099

http://doi.org/10.17576/jsm-2021-5004-19

\title{
The Effect of Bioactive Glass and Sintering Conditions on the Properties of Titanium-Hydroxyapatite Composites
}

(Kesan Kaca Bioaktif dan Keadaan Pensinteran pada Sifat Bahan Komposit Titanium-Hidroksiapatit)

\author{
Mohamed Abdulmunem*, Muralithran G. Kutty, Wan Haliza binti Abd Majid, Ali DabBagh, Noor \\ HAYATY ABU KASIM, NOOR AZLIN BINTI YAHYA \& HADIJAH ABDULLAH
}

\begin{abstract}
Titanium-hydroxyapatite (Ti-HA) based composites have been widely investigated as viable materials to be used in dentistry. However, sintering of these composites is very challenging due to decomposition of HA and oxidation of Ti. The objective of this study was to investigate the effect of incorporating a bioactive glass in Ti-HA composites sintered in different atmospheric conditions. The bioactive glass was prepared and added to different percentages of Ti-HA mixtures and divided into two groups. Samples in Group 1 were sintered with air atmosphere, while samples in Group 2 were sintered with vacuum furnace. All samples were later subjected to XRD, SEM, density, micro-hardness, and compression strength tests. XRD results showed that in Group 1, the major phases were assigned to Ti and HA while the minor phases were assigned to oxidised Ti. Whereas, Group 2 showed that the major phases were assigned to HA and the minor phases showed decomposition of $\mathrm{HA}$ to $\mathrm{Ca}_{3}\left(\mathrm{PO}_{4}\right)_{2}(\mathrm{TCP})$ and $\mathrm{Ca}_{4}\left(\mathrm{PO}_{4}\right)_{2} \mathrm{O}(\mathrm{TTCP})$. Oxidized Ti was also present in this group. In terms of density, micro-hardness and compression strength, statistical analyses showed that samples in Group 1 have a significant difference $(\mathrm{p}=0.000)$ as compared to those in Group 2. Sintering Ti-HA composites incorporated with BG by using air atmosphere furnace could reduce the decomposition of HA and oxidation of Ti, thus improve the density, micro-hardness and compression strength of the composites.
\end{abstract}

Keywords: Bioactive glass; composites; compression strength; hydroxyapatite; sintering process; titanium

ABSTRAK

Asas komposit titanium-hidroksiapatit (Ti-HA) telah dikaji secara meluas sebagai bahan berdaya maju yang digunakan dalam bidang pergigian. Akan tetapi, pensinteran komposit ini adalah sangat mencabar disebabkan penguraian bahan HA dan pengoksidan Ti. Objektif kajian ini adalah untuk mengkaji kesan memasukkan kaca bioaktif dalam komposit Ti-HA yang disinter dalam keadaan atmosfera yang berbeza. Kaca bioaktif disediakan dan ditambahkan kepada peratusan campuran Ti-HA yang berbeza dan dibahagikan kepada dua kumpulan. Sampel dalam Kumpulan 1 disinter dengan atmosfera udara, sementara sampel dalam Kumpulan 2 disinter dengan relau vakum. Semua sampel kemudiannya menjalani ujian XRD, SEM, ketumpatan, kekerasan mikro dan kekuatan mampatan. Hasil XRD menunjukkan bahawa dalam Kumpulan 1, fasa utama ditujukan untuk Ti dan HA sementara fasa minor ditujukan untuk Ti yang teroksidaan. Manakala, Kumpulan 2 menunjukkan bahawa fasa utama ditujukan untuk HA dan fasa minor menunjukkan penguraian HA ke Ca3 (PO4) 2 (TCP) dan Ca4 (PO4) $2 O$ (TTCP). Ti yang teroksidaan juga hadir dalam kumpulan ini. Dari segi ketumpatan, kekerasan mikro dan kekuatan mampatan, analisis statistik menunjukkan bahawa sampel dalam Kumpulan 1 mempunyai perbezaan yang signifikan ( $\mathrm{p}=0$,000) berbanding dengan kumpulan 2. Sintering Ti-HA komposit yang digabungkan dengan kaca bioaktif menggunakan relau atmosfera udara dapat mengurangkan penguraian HA dan pengoksidaan Ti, sehingga meningkatkan ketumpatan, kekerasan mikro dan kekuatan mampatan komposit.

Kata kunci: Hidroksiapatit; kaca bioaktif; kekuatan mampatan; komposit; proses pensinteran; titanium

\section{INTRODUCTION}

Ti-HA composites are being widely studied for utilization in medical applications. In dentistry, researches have been done to use this composite as dental posts. These composites have been used to produce functionally graded (multi-layer) dental posts. These dental posts are usually composed of different layers of Ti-HA composites (Dabbagh et al. 2019; Kasim et al. 2011). Kasim et al. (2011) have 
patented three types of functionally graded dental posts based on $\mathrm{ZrO}_{2}$-Ti-HA, $\mathrm{Al}_{2} \mathrm{O}_{3}$-Ti-HA and Ti-HA materials. The purpose of these functionally graded dental posts was to have high stiffness at the coronal layers and gradually decrease in stiffness to the apical layers to dissipate the stress from the post to the dental structures uniformly with the intent that any failure that occurs would be restorable failures. However, the produced posts were sintered at a high temperature $\left(1100^{\circ} \mathrm{C}\right)$, which was believe to cause oxidation and decomposition of Ti-HA composites when sintered together (Balbinotti et al. 2011).

Hydroxyapatite has similar chemical compositions of bone and tooth structures, making it the biomaterial of choice in many dental and medical applications. It has good bioactive behaviours, such as osseo-integration and osteoconduction (Camargo et al. 2018; Gunawan 2014; Mendelson et al. 2010). It is biocompatible with human hard tissue and has been widely used in many studies (Karimi et al. 2015; Nandi et al. 2009; Santhosh \& Prabu 2013; Zhou et al. 2014). Unfortunately, it is brittle, has poor mechanical properties and unable to withstand high forces during load applications (Gunawan et al. 2013; Mendelson et al. 2010; Veljović et al. 2011). In contrast to HA, titanium has good mechanical properties and anti-corrosion abilities, involving in many industries and synthesis of many medical and dental applications. On the other hand, titanium has poor biocompatibility behaviour as compared to HA (Aldousari et al. 2018; Arifin et al. 2014; Brunette et al. 2012; Li et al. 2017).

Combining Ti and HA to form a Ti-HA composites could provide a material with good biocompatibility and good mechanical properties (Balbinotti et al. 2011). However, consolidation of a Ti-HA composite via sintering is challenging as high temperature needed by this process can cause the decomposition of HA and oxidation of titanium which will weaken the produced composite (Balbinotti et al. 2011).

One method of solving this problem is to add low melting materials to the Ti-HA composite that allows it to be sintered at a lower temperature, thus maintain the properties of the composite and avoid the decomposition of HA (Ning \& Zhou 2008). Bioactive Glass (BG) is a silicate-based material with high biocompatibility and shows osteoconductive abilities which can form hydroxyapatite layer when connected to the body. Its use has shown to be ideal in many medical and dental applications, including scaffold, bone graft, coating materials, and treating teeth hypersensitivity (Boccaccini et al. 2010; Prasad et al. 2017; Vitale-Brovarone et al. 2012).

$\mathrm{BG}$ could be the material of choice and good additives to be used as a sintering aid in Ti-HA composites. BG can reduce the sintering temperature of Ti-HA composite and could also improve the mechanical and bioactivity properties of Ti-HA composites as was reported in a study by Ning and Zhou (2004). However, the produced samples in that study showed decomposition of HA and oxidation of Ti. This negative outcome could be due to the high sintering temperatures $\left(1000-1200{ }^{\circ} \mathrm{C}\right)$ used during sintering in a hot press furnace.

Due to the above-mentioned challenges, this study aimed to reduce the decomposition of HA and oxidation of $\mathrm{Ti}$ in Ti-HA composites by incorporation of BG, lowering the sintering temperature and using different sintering conditions. In this study, the effect of the bioactive glass and sintering conditions on Ti-HA-BG composites in terms of X-ray diffraction (XRD), scanning electronic microscope (SEM), density, micro-hardness, and compression strength were investigated.

Five different Ti-HA-BG composites were produced in this study to match the concept of the functionally graded dental post which reported to have a gradual decrease in stiffness from first layer to the last layer (Kasim et al. 2011). In this study, the layers (composites) were produced separately in order to be evaluated before producing a functionally graded dental post.

\section{MATERIALS AND METHODS}

\section{BIOACTIVE GLASS POWDER PREPARATION}

The bioactive glass used for this study was prepared based on a previous work done by Ning and Zhou (2004). It was produced by milling eight different materials with different percentages; $48 \% \mathrm{SiO}_{2} 10 \% \mathrm{NaO}, 13 \% \mathrm{CaO}$, $9.2 \% \mathrm{P}_{2} \mathrm{O}_{5}, 9.7 \% \mathrm{~B}_{2} \mathrm{O}_{3}, 4.25 \% \mathrm{TiO}_{2}, 0.98 \% \mathrm{CaF}_{2}$, and $4.87 \%$ $\mathrm{MgO}$. These materials were weighed (OHAUS, Pioneer ${ }^{\mathrm{TM}}$, USA) and then milled together by using a planetary ball milling machine (XQM, China) at $200 \mathrm{rpm}$ to produce bioactive glass.

\section{TI-HA-BG COMPOSITES PREPARATION}

Ti-HA-BG mixtures were prepared using a commercially available titanium powder (average particle size $\sim 45 \mu \mathrm{m}$ ), and Hydroxyapatite (average particle size $\sim 5 \mu \mathrm{m}$ ) (SigmaAldrich, Germany) powders. Subsequently, a fixed 10\% bioactive glass was added to five different percentages of Ti-HA mixtures (Table 1) and all were milled for $5 \mathrm{~h}$.

Moulds were made by using silicone impression materials (Aquasil; Dentsply) and the mixtures were poured into these moulds with each layer prepared separately. The moulds were then sealed with the same impression materials to facilitate pressing of the samples. Then, 100 samples were sent to be compacted by using a cold isostatic press with pressure of $250 \mathrm{MPa}$. Moulds 
were then removed and the samples were divided into two main groups (each of 50 samples). Each group has five layers, in which each layer has 10 samples. In Group
1, the samples were sintered with air atmosphere furnace (Muffle Nabertherm, Germany), while in Group 2, the samples were sintered with vacuum furnace. Samples in both groups were sintered at $900{ }^{\circ} \mathrm{C}$ as shown in Figure 1 .

TABLE 1. Samples distribution in the Groups (air atmosphere and vacuum furnaces) and layers

\begin{tabular}{|c|c|c|c|c|}
\hline Layers & Group 1 (air atmosphere furnace) & n.* & Group 2 (vacuum furnace) & $\mathrm{n}$. \\
\hline layer 1 & $\begin{array}{c}\text { Ti } 90 \% \\
\text { BG } 10 \% .\end{array}$ & 23 & $\begin{array}{c}\text { Ti } 90 \% \\
\text { BG } 10 \% .\end{array}$ & 23 \\
\hline layer 2 & $\begin{array}{c}\text { Ti } 70 \% \\
\text { HA 20\% } \\
\text { BG 10\%. }\end{array}$ & 23 & $\begin{array}{c}\text { Ti } 70 \% \\
\text { HA 20\% } \\
\text { BG } 10 \% .\end{array}$ & 23 \\
\hline layer 3 & $\begin{array}{c}\text { Ti } 45 \% \\
\text { HA } 45 \% \\
\text { BG } 10 \% .\end{array}$ & 23 & $\begin{array}{c}\text { Ti } 45 \% \\
\text { HA } 45 \% \\
\text { BG } 10 \% .\end{array}$ & 23 \\
\hline layer 4 & $\begin{array}{c}\text { Ti } 20 \% \\
\text { HA } 70 \% \\
\text { BG } 10 \% .\end{array}$ & 23 & $\begin{array}{c}\text { Ti } 20 \% \\
\text { HA } 70 \% \\
\text { BG } 10 \% .\end{array}$ & 23 \\
\hline layer 5 & $\begin{array}{l}\text { HA } 90 \% \\
\text { BG } 10 \% .\end{array}$ & 23 & $\begin{array}{l}\text { HA } 90 \% \\
\text { BG } 10 \% .\end{array}$ & 23 \\
\hline
\end{tabular}

$*_{\mathrm{n}}=$ Number of samples

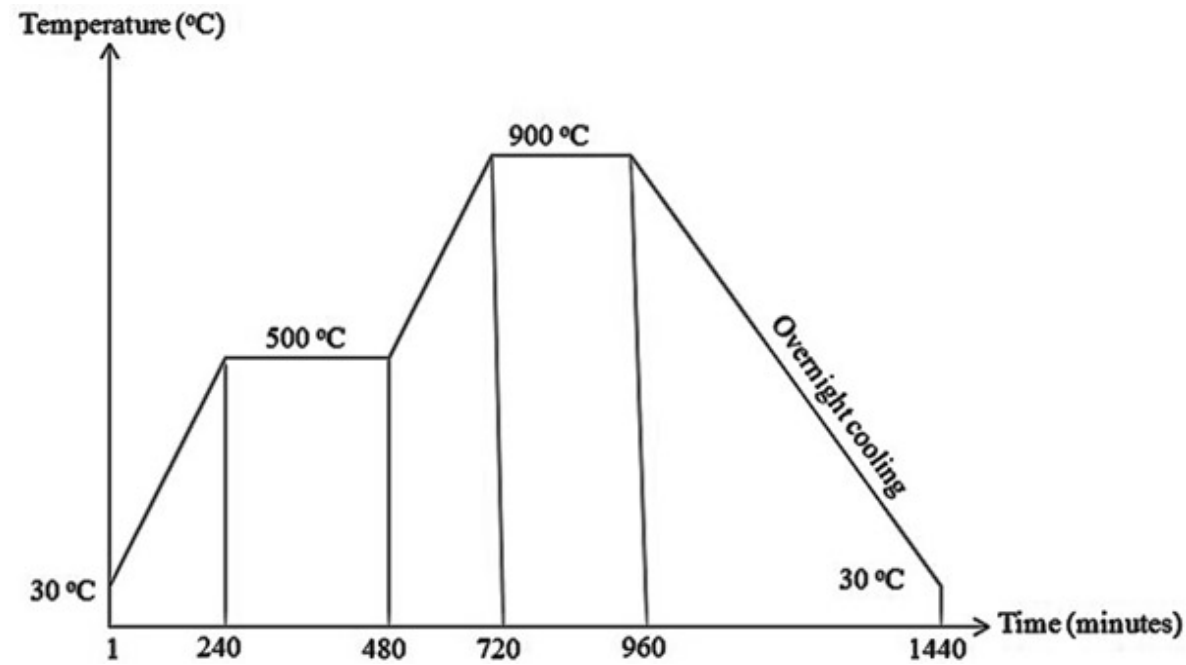

FIGURE 1. Sintering cycle of the samples from room temperature to $900{ }^{\circ} \mathrm{C}$ 


\section{TESTING OF COMPOSITES}

After sintering, a total of 30 disc-shaped samples with a diameter of $10 \mathrm{~mm}$ and a thickness of $5 \mathrm{~mm}$ (each group of 15 samples and each layer of 3 ) were sent for X-ray diffraction (XRD: Philips PW1840). All XRD data were analysed by using X'Pert HighScore software (X'Pert Pro, Panalytical, Netherlands). Samples were then subjected to scanning electronic microscope (SEM; Quanta 250 FEG, FEI Inc., USA) to check the surface morphology. The density was measured for hundred samples (each group of 50 disc-shaped samples and each layer of 10) by using a densitometer (Sartorius AX224, Germany) and the values were calculated by using the Archimedes' principle. Samples were also subjected to micro-hardness test (Vickers Hardness tester, HMV- Shimadzu) by applying three indentations with a load of $4.90 \mathrm{~N}$ for 15 s. Meanwhile 100 cylindrical-shaped samples, $10 \mathrm{~mm}$ in diameter, and $12 \mathrm{~mm}$ in length (each group of 50 samples and each layer of 10) were used for compression strength test. Samples were compressed using a load of $5 \mathrm{KN}$ with a cross-head speed of $0.5 \mathrm{~mm} / \mathrm{min}$ using the universal testing machine (Shimadzu).

\section{RESULTS}

\section{XRD ANALYSIS}

The X-ray Diffraction (XRD) patterns for Group 1 (G 1) are shown in Figure 2. XRD pattern of layer 1 showed that the majority of titanium had retained stability and matched JCPDS card no. 44-1294. Meanwhile, some titanium oxide in the form of $\mathrm{Ti}_{2} \mathrm{O}$ (JCPDS card no. 01073-1116) and TiO (JCPDS card no. 65-2900), were also detected. In the intermittent layers of 2, 3, and 4 where Ti gradually reduced and HA (JCPDS card no. 009-0432) increased, there was no decomposition of HA detected. In layer 5, the crystalline phase mostly belonged to HA.

For Group 2 (G 2), XRD patterns are listed in Figure 3. Samples in this group were sintered in a vacuum furnace. Layer 1 showed that the major phases belong to $\mathrm{Ti}$ and also there was presence of $\mathrm{Ti}_{2} \mathrm{O}$ and $\mathrm{TiO}$. The intermittent layers (layers 2, 3, and 4) also showed that $\mathrm{Ti}$ phases gradually reduced and HA increased. In addition, $\mathrm{Ti}_{2} \mathrm{O}, \mathrm{TiO}_{2}$, TTCP (JCPDS card no. 00-025-1137), and TCP (JCPDS card no. 00-009-0348) were present in these layers. In layer 5, most of the major peaks belong to HA. However, HA also decomposed into TTCP and TCP which were the minor phases of this layer.

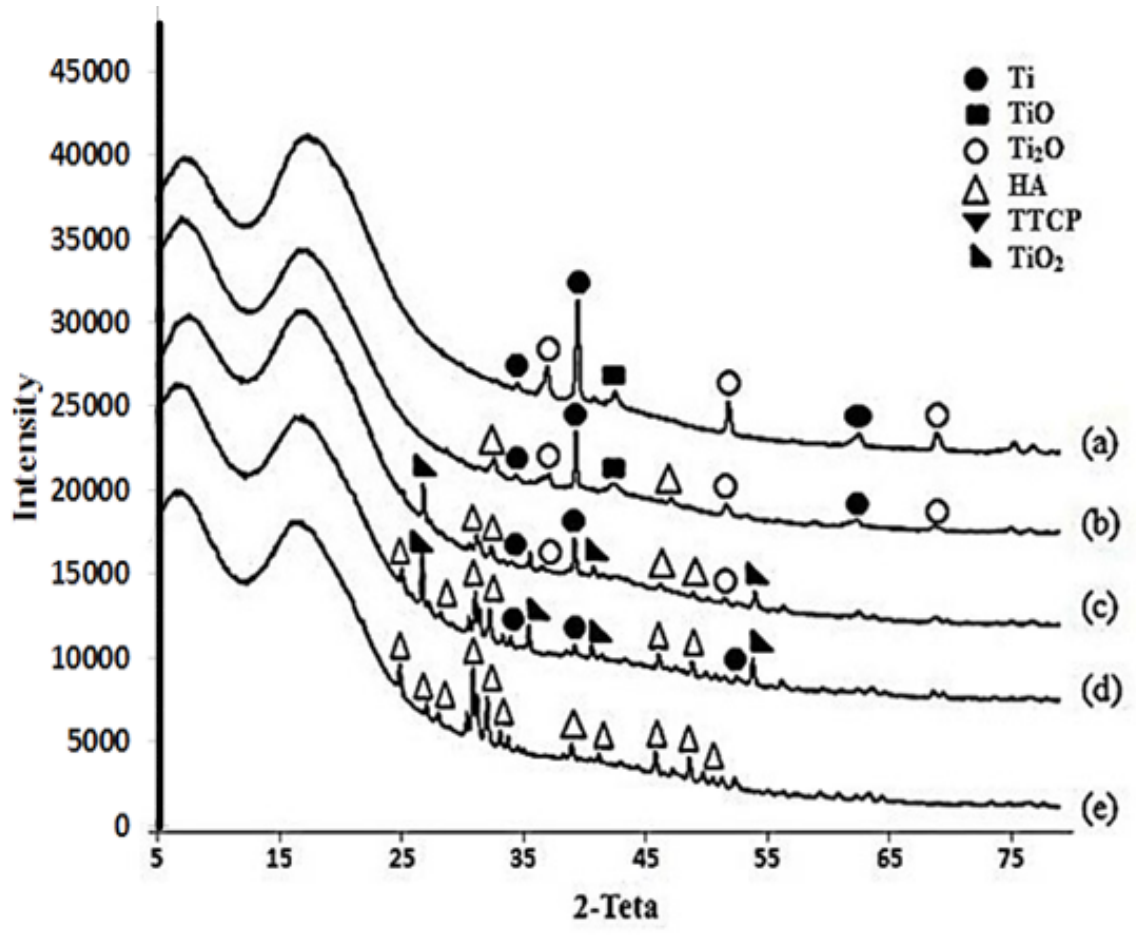

FIGURE 2. XRD of 5 layers sintered with air atmosphere furnace (a) Layer 1, (b) Layer 2, (c) Layer 3, (d) Layer 4, and (e) Layer 5 


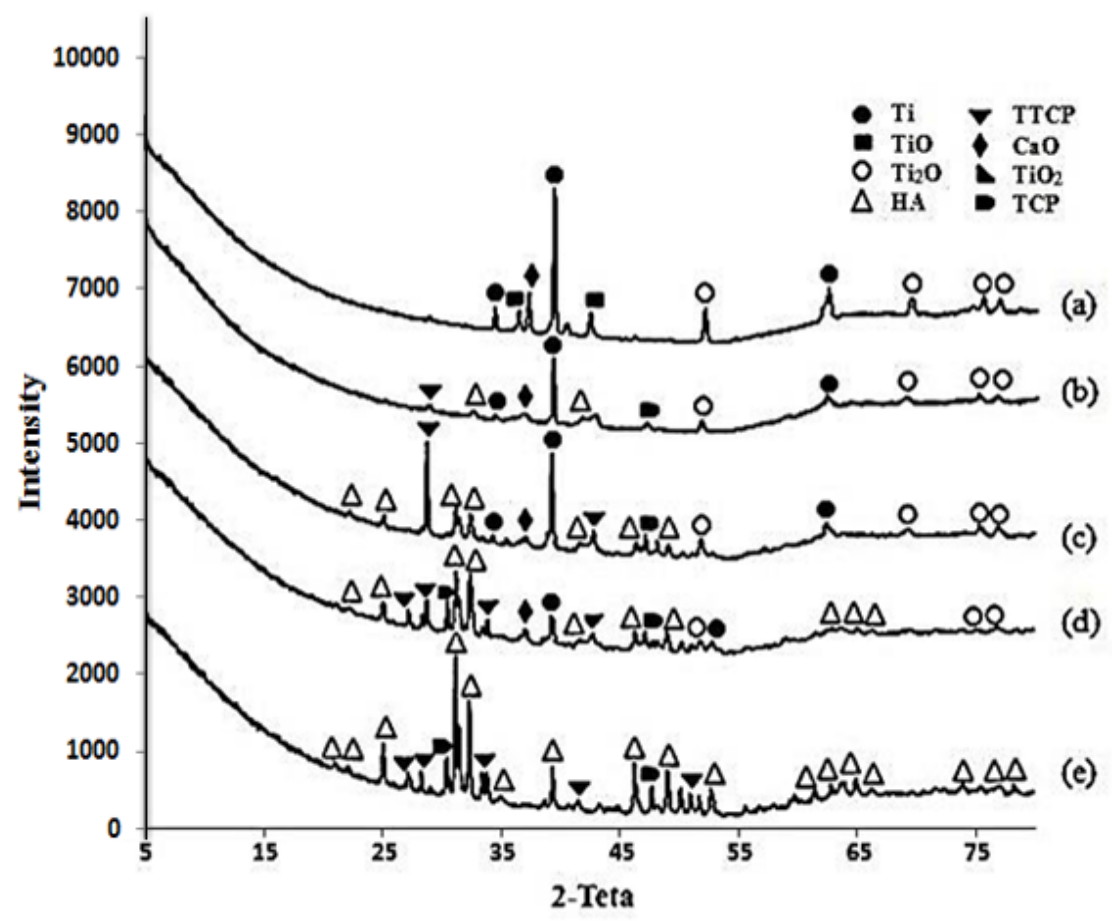

FIGURE 3. XRD of 5 layers sintered with vacuum furnace (a) Layer 1, (b) Layer 2, (c) Layer 3, (d) Layer 4, and (e) Layer 5

\section{DENSITY AND SEM}

In both groups, layers with high Ti ratio (layers 1 and 2) showed higher density than those with low Ti ratios (layers 3-5). Ti ratio was gradually decreased from layers 1 to 5 and hence the density gradually decreased too. Means, standard deviations and multiple comparisons are listed in Table 2. The SEM images of different layers are shown in Figure 4. The images showed that there was no clear difference in the morphology of the layers in both groups.
Moreover, there was no clear evidence of porosity on the surface.

Layers sintered in air atmosphere furnace group $(\mathrm{G}$ 1) showed significantly higher density than those sintered in vacuum furnace group $(\mathrm{G} 2)(p=0.000)$. Layer 3 that sintered in air atmosphere furnace showed a significantly higher density $(p=0.027)$ than layer 3 that was sintered in a vacuum furnace. Whereas, there was no significant difference between the other layers that was sintered in air atmosphere and vacuum furnaces.

TABLE 2. Multiple comparison of density of composites layers sintered in air atmosphere and vacuum furnaces

\begin{tabular}{|c|c|c|c|c|c|c|}
\hline \multirow[b]{2}{*}{ Layers } & \multirow[b]{2}{*}{ Type of furnace } & \multirow[b]{2}{*}{ n.* } & \multirow{2}{*}{$\begin{array}{l}\text { Stress score } \\
\text { Mean (SD) }\end{array}$} & \multicolumn{2}{|c|}{$95 \%$ Confidence interval } & \multirow[b]{2}{*}{$P$ value } \\
\hline & & & & Lower bound & Upper bound & \\
\hline \multirow{2}{*}{ Layer 1} & Air atmosphere furnace & 10 & $4.62(0.27)$ & & & \\
\hline & Vacuum furnace & 10 & $4.44(0.162)$ & -0.1423 & 0.5031 & 0.725 \\
\hline \multirow{2}{*}{ Layer 2} & Air atmosphere furnace & 10 & $3.92(0.27)$ & & & \\
\hline & Vacuum furnace & 10 & $3.73(0.240)$ & -0.1349 & 0.5105 & 0.677 \\
\hline
\end{tabular}




\begin{tabular}{|c|c|c|c|c|c|c|}
\hline \multirow{2}{*}{ Layer 3} & Air atmosphere furnace & 10 & $3.53(0.013)$ & & & \\
\hline & Vacuum furnace & 10 & $3.18(0.28)$ & 0.0218 & 0.6673 & 0.027 \\
\hline \multirow{2}{*}{ Layer 4} & Air atmosphere furnace & 10 & $3.17(0.11)$ & & & \\
\hline & Vacuum furnace & 10 & $2.93(0.18)$ & -0.0782 & 0.5672 & 0.305 \\
\hline \multirow[b]{2}{*}{ Layer 5} & Air atmosphere furnace & 10 & $2.89(0.28)$ & & & \\
\hline & Vacuum furnace & 10 & $2.63(0.20)$ & -0.0620 & 0.5835 & 0.223 \\
\hline
\end{tabular}

${ }^{*} \mathrm{n} .=$ Number of samples
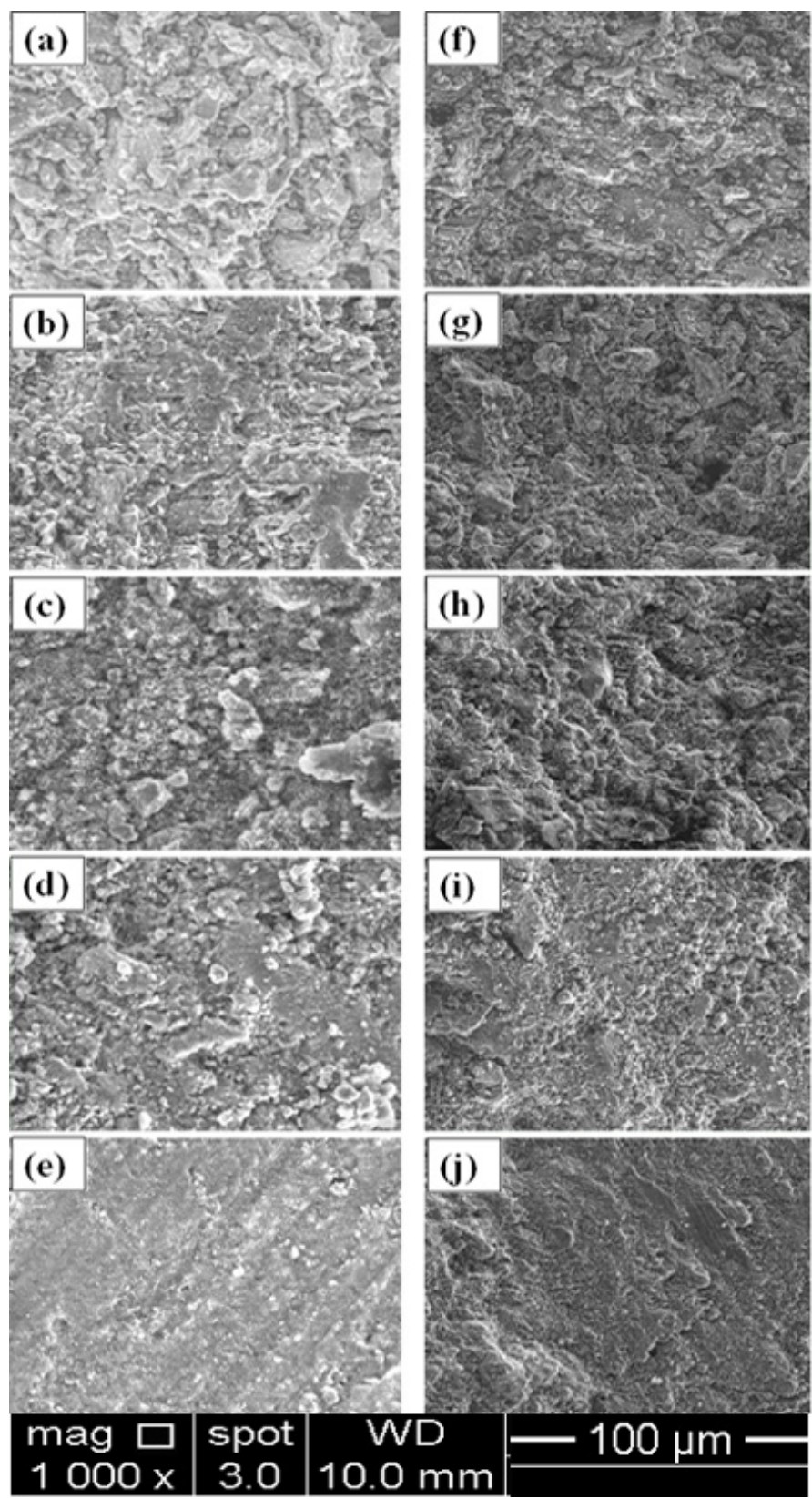

FIGURE 4. SEM images of layers in G 1 and G 2 (a) Layer 1 (G 1), (b) Layer 2 (G

1), (c) Layer 3 (G 1), (d) Layer 4 (G 1), (e) Layer 5 (G 2), (f) Layer 1 (G 2), (g) Layer 2 (G 2), (h) Layer 3 (G 2), (i) Layer 4 (G 2), and (j) Layer 5 (G 2) 


\section{MICRO-HARDNESS}

Two-way ANOVA was performed to check the significant difference between the main groups. T-test was also applied to determine the differences between the layers in both groups. Results in both groups showed that layers with high Ti ratio (layers 1 and 2) showed higher microhardness than those with low Ti ratios (layers 3-5). As a result of gradual decrease in Ti ratio, the micro-hardness also gradually decreased from layer 1-5. Means, standard deviations and multiple comparisons are listed in Table 3. Samples sintered in air atmosphere furnace $(\mathrm{G} 1)$ showed higher micro-hardness than those sintered in vacuum $(\mathrm{G}$ 2) $(p=0.000)$. All layers that sintered in air atmosphere furnace showed a significant higher micro-hardness compared to all layers sintered in vacuum furnace.

\section{COMPRESSION STRENGTH}

Compression strength of layers in both groups was affected by Ti ratio. As a result of a gradual decrease in Ti ratio from layer 1 to layer 5 , the compression strength also gradually decreased. Means, standard deviations and multiple comparisons are listed in Table 4. Two-way ANOVA results showed that the samples sintered in air atmosphere furnace $(\mathrm{G} 1)$ displayed higher compression strength than those sintered in a vacuum furnace $(G$ 2) $(p=0.000)$. T-test was also performed to determine the differences between the layers in both groups. There was a significant difference between layers (1-4) in $\mathrm{G} 1$ ( $p$ $=0.000$ ) compared to those in $\mathrm{G} 2$. Layer 5 in $\mathrm{G} 1$ also showed a significant difference compared to that in $\mathrm{G} 2$ $(p=0.032)$

TABLE 3. Multiple comparison of micro-hardness of composites layers sintered in air atmosphere and vacuum furnaces

\begin{tabular}{|c|c|c|c|c|c|c|}
\hline \multirow[b]{2}{*}{ Layers } & \multirow[b]{2}{*}{ Type of furnace } & \multirow[b]{2}{*}{ n.* } & \multirow{2}{*}{$\begin{array}{l}\text { Stress score } \\
\text { Mean (SD) }\end{array}$} & \multicolumn{2}{|c|}{$95 \%$ Confidence interval } & \multirow[b]{2}{*}{$P$ value } \\
\hline & & & & Lower bound & Upper bound & \\
\hline \multirow{2}{*}{ Layer 1} & Air atmosphere furnace & 10 & 342 (21.29) & & & \\
\hline & Vacuum furnace & 10 & $234(9.62)$ & 87.9751 & 127.2249 & 0.000 \\
\hline \multirow[b]{2}{*}{ Layer 2} & Air atmosphere furnace & 10 & $312(22.41)$ & & & \\
\hline & Vacuum furnace & 10 & $201(7.29)$ & 90.5751 & 129.8249 & 0.000 \\
\hline \multirow[b]{2}{*}{ Layer 3} & Air atmosphere furnace & 10 & $185(16.45)$ & & & \\
\hline & Vacuum furnace & 10 & $136(9.28)$ & 29.8751 & 9.1249 & 0.000 \\
\hline \multirow[b]{2}{*}{ Layer 4} & Air atmosphere furnace & 10 & $160(11.35)$ & & & \\
\hline & Vacuum furnace & 10 & $128(8.36)$ & 12.5751 & 51.8249 & 0.000 \\
\hline \multirow{2}{*}{ Layer 5} & Air atmosphere furnace & 10 & $150(9.91)$ & & & \\
\hline & Vacuum furnace & 10 & $124(8.55)$ & 6.0751 & 45.3249 & 0.002 \\
\hline
\end{tabular}

$*_{\mathrm{n}}=$ Number of samples. 
TABLE 4. Multiple comparison of compression strength of composites layers sintered in air atmosphere and vacuum furnaces

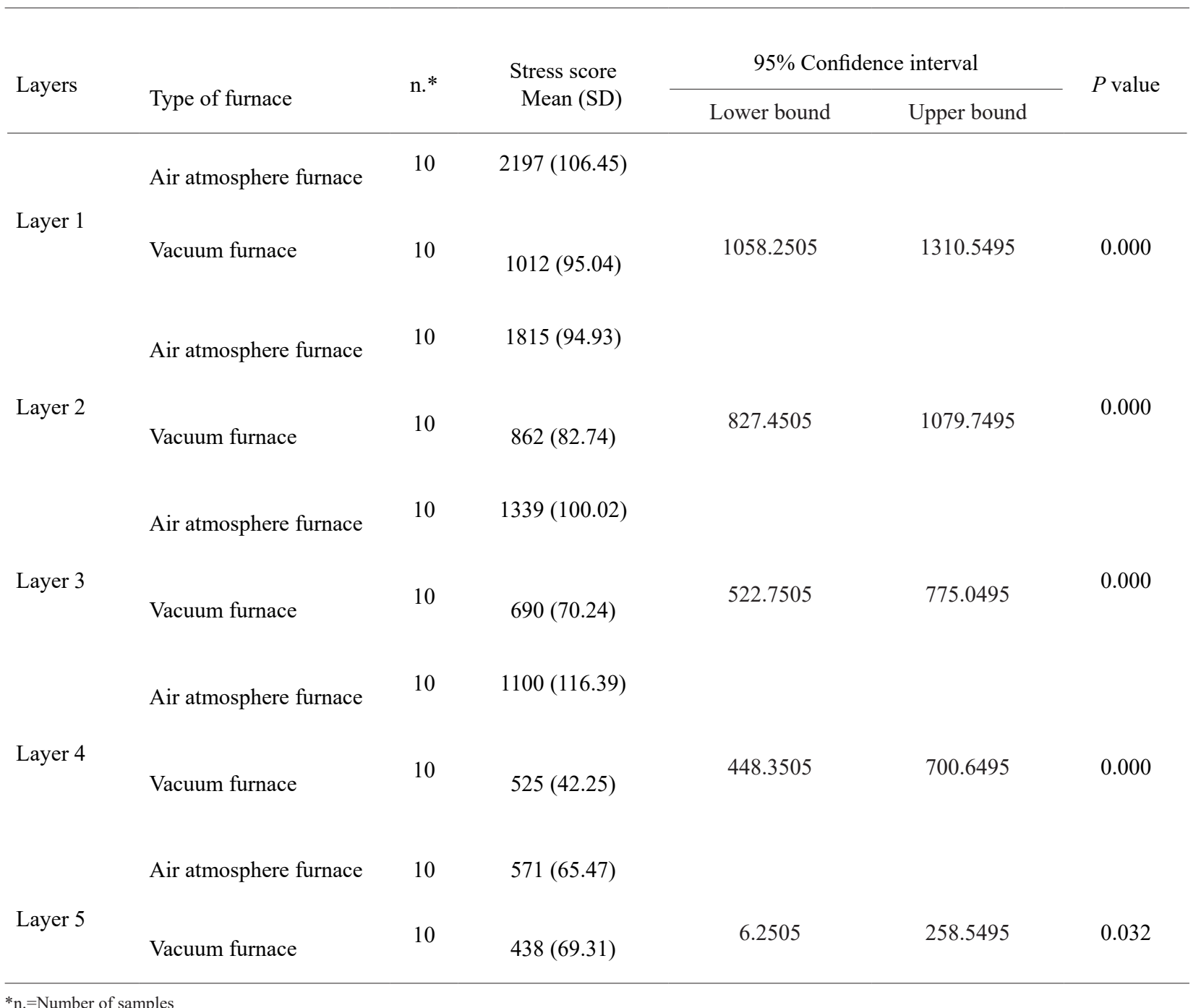

$*_{n}$. $=$ Number of samples

\section{DISCUSSION}

Many studies were done on sintering HA and Ti in air atmosphere and in vacuum or in Argon atmosphere furnaces. Results suggested that HA should be sintered in air furnace to minimise the decomposition where sintering HA in non-air furnace will cause dihydroxylation of HA (losing of -OH from HA) and then the decomposition to TCP and TTCP will also occur. Other studies suggested that $\mathrm{Ti}$ should be sintered in vacuum or in Argon atmosphere furnaces to reduce oxidation process (Arifin et al. 2014; Goudarzi et al. 2014; Marcelo et al. 2006; Wakily et al. 2015; Weng et al. 1994). Merging them in one composite and sintering the composite at high temperature in an environment furnace will cause oxidation and decomposition of Ti-HA materials to TTCP, TCP, $\mathrm{Ti}_{2} \mathrm{O}$, and TiO (Arifin et al. 2014; Goudarzi et al. 2014; Marcelo et al. 2006). In this study, these sintering challenges could be solved by incorporating the Ti-HA composites with $\mathrm{BG}$ and thus the sintering temperature reduced to $900{ }^{\circ} \mathrm{C}$.

\section{XRD}

In this study, the five layers sintered in air atmosphere furnace showed the expected results. The XRD analysis indicated that the major peaks and phases in this group for all layers belonged to the main materials used in the 
fabricated composites. In layer 1, peaks and major phases belonged to $\mathrm{Ti}$. Titanium showed some oxidation to $\mathrm{TiO}$ and $\mathrm{Ti}_{2} \mathrm{O}$ while $\mathrm{TiO}_{2}$ was not detected in this layer. TiO was oxidised to $\mathrm{TiO}_{2}$ in layers 3 and 4 . Titanium was gradually decreased in ratio from layers 1 to 4 and completely disappeared in layer 5 since no Ti was added in this layer. These results were in agreement with previous studies, which have indicated that $\mathrm{Ti}$ started to oxidise to $\mathrm{TiO}$ and $\mathrm{Ti}_{2} \mathrm{O}$ at 700 and $850{ }^{\circ} \mathrm{C}$ (Arifin et al. 2015; Balbinotti et al. 2011; Comín et al. 2017). HA was observed in every other layer from layers 2 to 5 . There was no HA decomposition detected in all HA layers (2-5) and thus, HA was totally intact.

The XRD analysis showed that there were no diffraction peaks related to $\mathrm{BG}$ because $\mathrm{BG}$ amorphous phase occurs at $600{ }^{\circ} \mathrm{C}$, while at $800{ }^{\circ} \mathrm{C}$, all diffraction peaks were converted to HA, as was reported by Ning and Zhou (2004). They concluded that BG could improve the bioactivity and properties of Ti-HA composites and also the sintering process of these composites. This was in agreement with the results of the current study at which BG improved the sintering of Ti-HA composites by preventing the HA decomposition and the complete Ti oxidation when sintered in air atmosphere furnace. It is noted that composites in this study were sintered at 900 ${ }^{\circ} \mathrm{C}$ to produce a stable composite below HA decomposition temperature and to avoid $\mathrm{Ti}$ oxidation. It was also reported that when $\mathrm{HA}$ and $\mathrm{Ti}$ are sintered together, the HA decomposition occurs at $1250{ }^{\circ} \mathrm{C}$ in air and at 1050 ${ }^{\circ} \mathrm{C}$ when sintered in vacuum furnace, while Ti started to oxidise at $800{ }^{\circ} \mathrm{C}$ (Balbinotti et al. 2011; Comín et al. 2017). Therefore, no HA decomposition was detected in the layers sintered in air atmosphere furnace in this study because they were sintered below HA decomposition temperature at $900{ }^{\circ} \mathrm{C}$.

The main phases of the five layers sintered in vacuum furnace belonged to $\mathrm{Ti}$ and the minor phases belonged to $\mathrm{TiO}, \mathrm{Ti}_{2} \mathrm{O}$, and $\mathrm{TiO}_{2}$. In the layers that contained HA, decomposition to $\mathrm{CaO}$, TCP, and TTCP were noticed from layers 2 to 5 . The observations are in agreement with many studies which reported HA decomposition when Ti-HA was sintered in vacuum or argon atmosphere furnace (Arifin et al. 2015; Balbinotti et al. 2011; Comín et al. 2017).

\section{DENSITY, MICRO-HARDNESS AND COMPRESSION STRENGTH}

A chemical composition is the most important factor that affects the physical and mechanical properties of the fabricated Ti-HA-BG composites in this study. The decomposed and oxidised components were weaker than Ti and HA, and thus will reduce the strength and hardness of the composites (Prasad et al. 2017).

Composites sintered in air atmosphere furnace showed higher density than those sintered in vacuum furnace. The reason is because composites sintered in air did not show HA decomposition for all 5 layers (composites) while those sintered in vacuum showed some decomposition of HA to composite with low density, such as TCP $\left(3.07 \mathrm{~g} / \mathrm{cm}^{3}\right)$ and TTCP $\left(3.06 \mathrm{~g} / \mathrm{cm}^{3}\right)$ as compared to that of HA. The density and mechanical properties of the fabricated Ti-HA-BG will be affected, as reported in previous studies (Bodhak et al. 2011; Comín et al. 2017; Prasad et al. 2017; Wakily et al. 2015). In general, layers with high ratio of Ti showed a higher density than those with none or lower ratio of Ti. That was because the density of $\mathrm{Ti}\left(4.5 \mathrm{~g} / \mathrm{cm}^{3}\right)$ was higher than that of HA $\left(3.156 \mathrm{~g} / \mathrm{cm}^{3}\right)$ and BG $\left(2.707 \mathrm{~g} / \mathrm{cm}^{3}\right)$ (Arifin et al. 2015; Srivastava et al. 2012).

Micro-hardness of layers sintered in air atmosphere (G 1) was higher compared to those sintered in vacuum furnace (G 2). Since no HA decomposition was detected in all layers in $G 1$, the HA remained intact and thus improved the hardness of these layers. Intact HA were reported to have higher micro-hardness values compared to the decomposed compositions such as TCP and TTCP (Arifin et al. 2015, 2014). Intact Ti also affected the hardness results at which Ti has higher physical and mechanical properties compared to the oxidized $\mathrm{Ti}$ (Arifin et al. 2015, 2014; Prasad et al. 2017). Worthy to mention, micro-hardness should increase in layers with high HA ratio and low Ti ratio as HA hardness (4.72 $\mathrm{GPa})$ is higher than that of Ti $(3.09 \mathrm{GPa})$ (Chenglin et al. 1999). However, results in this study showed that layers with higher Ti ratio (layers 1 and 2) have higher microhardness compared to those with higher HA ratio (layers 3-5). That was because layers with high Ti ratio have higher density which could affect the hardness of Ti-HA layers (Arifin et al. 2015; Chenglin et al. 1999; Shahrjerdi et al. 2011).

The results of compression strength in this study were higher in layers with higher Ti ratios compared to those with lower Ti ratios. The compression strength decreased gradually combined with the decrease in $\mathrm{Ti}$ ratio (from layer 1-5, respectively). Similar findings were reported by Shahrjerdi et al. (2011). That is because Ti has better mechanical properties as compared to HA and oxidized Ti (Arifin et al. 2014; Balbinotti et al. 2011; Wakily et al. 2015). Hence, layers sintered in air atmosphere showed higher compression strength than those 
sintered in vacuum furnace at which a decomposition and oxidation Ti-HA were minimised. Balbinotti et al. (2011) had reported that increasing of HA ratio in TiHA composites reduce the compression strength, thus composites with high Ti ratio will have higher values than those with low Ti or high HA ratios.

In general, chemical, physical, and mechanical properties of Ti-HA composites were significantly better when sintered in air atmosphere compared to those sintered in vacuum. Moreover, Ti-HA composites can be incorporated with bioactive glass to maintain the properties intact after sintering at low temperature degree, as reported in this study and mentioned by previous studies (Ning \& Zhou 2004; Prasad et al. 2017).

\section{CONCLUSION}

Adding BG to Ti-HA composites could reduce the sintering temperature to $900{ }^{\circ} \mathrm{C}$ and maintain the properties of $\mathrm{Ti}$ and HA. Sintering the Ti-HA-BG composites in air atmosphere furnace could minimise the decomposition of HA and oxidation of Ti. Thus, improve the micro-hardness and compression strength of the Ti-HA-BG composites. Moreover, Ti-HA-BG composite layers that were studied in this research work have promising properties that can be used in fabrication of a functionally graded dental post.

\section{ACKNOWLEDGEMENTS}

This research was supported by the FRGS Grant No. FP019-2017A from the Faculty of Dentistry, University of Malaya, Kuala Lumpur, Malaysia. The authors have no conflict of interest relevant to this article.

\section{REFERENCES}

Aldousari, S.M., Fouda, N., Hedia, H.S. \& AlThobiani, F.W.H. 2018. Comparison of titanium and FGM dental implants with different coating types. Materials Testing 60(2): 142-148.

Arifin, A., Sulong, A.B., Muhamad, N. \& Syarif, J. 2015. Characterization of hydroxyapatite/TI6AL4V composite powder under various sintering temperature. Jurnal Teknologi 75(7): 27-31.

Arifin, A., Sulong, A.B., Muhamad, N., Syarif, J. \& Ramli, M.I. 2014. Material processing of hydroxyapatite and titanium alloy (HA/Ti) composite as implant materials using powder metallurgy: A review. Materials \& Design 55: 165-175.

Balbinotti, P., Gemelli, E., Buerger, G., de Lima, S.A., de Jesus, J., Camargo, N.H.A., Henriques, V.A.R. \& Soares, G.D.d.A. 2011. Microstructure development on sintered Ti/HA biocomposites produced by powder metallurgy. Materials Research 14(3): 384-393.
Boccaccini, A.R., Erol, M., Stark, W.J., Mohn, D., Hong, Z. \& Mano, J.F. 2010. Polymer/bioactive glass nanocomposites for biomedical applications: A review. Composites Science and Technology 70(13): 1764-1776.

Bodhak, S., Bose, S. \& Bandyopadhyay, A. 2011. Influence of $\mathrm{MgO}, \mathrm{SrO}$, and $\mathrm{ZnO}$ dopants on electro-thermal polarization behavior and in vitro biological properties of hydroxyapatite ceramics. Journal of the American Ceramic Society 94(4): 1281-1288.

Brunette, D.M., Tengvall, P., Textor, M. \& Thomsen, P. 2012. Titanium in Medicine: Material Science, Surface Science, Engineering, Biological Responses and Medical Applications. Heidelberg, Germany: Springer Science \& Business Media. p. 391.

Camargo, N.H.A., Gemelli, E., Passoni, L.S., Franczak, P.F. \& Corrêa, P. 2018. Elaboration of a triphasic calcium phosphate and silica nanocomposite for maxillary grafting and deposition on titanium implants. International Journal of Materials Research 109(1): 68-75.

Chenglin, C., Jingchuan, Z., Zhongda, Y. \& Shidong, W. 1999. Hydroxyapatite-Ti functionally graded biomaterial fabricated by powder metallurgy. Materials Science and Engineering: A 271(1-2): 95-100.

Comín, R., Cid, M.A., Grinschpun, L., Oldani, C. \& Salvatierra, N.A. 2017. Titanium-hydroxyapatite composites sintered at low temperature for tissue engineering: in vitro cell support and biocompatibility. Journal of Applied Biomaterials \& Functional Materials 15(2): e176-e183.

Dabbagh, A., Madfa, A., Naderi, S., Talaeizadeh, M., Abdullah, H., Abdulmunem, M. \& Abu Kasim, N.H. 2019. Thermomechanical advantages of functionally graded dental posts: A finite element analysis. Mechanics of Advanced Materials and Structures 26(8): 700-709.

Goudarzi, M., Batmanghelich, F., Afshar, A., Dolati, A. \& Mortazavi, G. 2014. Development of electrophoretically deposited hydroxyapatite coatings on anodized nanotubular TiO2 structures: Corrosion and sintering temperature. Applied Surface Science 301: 250-257.

Gunawan, Sopyan, I., Suryanto \& Naqshbandi, A. 2014. Zinc-doped biphasic calcium phosphate nanopowders synthesized via sol-gel method. Indian Journal of Chemistry Section A 53A(2): 152-158.

Gunawan, Sopyan, I., Nurfaezah, S. \& Ammar, A. 2013. Development of triphasic calcium phosphate-carbon nanotubes (HA/TCP-CNT) composite: A preliminary study. Key Engineering Materials 531-532: 258-261.

Karimi, S., Mahzoon, F., Javadpour, S. \& Janghorban, K. 2015. Study of wear and corrosion behavior of cathodic plasma electrolytic deposition of zirconia-hydroxyapatite on titanium and 316L stainless steel in Ringer's solution. International Journal of Materials Research 106(6): 614-620.

Kasim, N.H.A., Madfa, A.A., Hamdi, M. \& Rahbari, G.R. 2011. 3D-FE analysis of functionally graded structured dental posts. Dental Materials Journal 30(6): 869-880.

Li, Y.H., Wang, F. \& Li, J.J. 2017. Current developments of biomedical porous Ti-Mo alloys. International Journal of Materials Research 108(8): 619-624. 
Marcelo, T.M., Vanessa, L., Oliveira, M.V.d. \& Carvalho, M.H. 2006. Microstructural characterization and interactions in Ti-and TiH2-hydroxyapatite vacuum sintered composites. Materials Research 9(1): 65-71.

Mendelson, B.C., Jacobson, S.R., Lavoipierre, A.M. \& Huggins, R.J. 2010. The fate of porous hydroxyapatite granules used in facial skeletal augmentation. Aesthetic Plastic Surgery 34(4): 455-461.

Nandi, S.K., Kundu, B., Ghosh, S.K., Mandal, T.K., Datta, S., De, D.K. \& Basu, D. 2009. Cefuroxime-impregnated calcium phosphates as an implantable delivery system in experimental osteomyelitis. Ceramics International 35(4): 1367-1376.

Ning, C. \& Zhou, Y. 2008. Correlations between the in vitro and in vivo bioactivity of the Ti/HA composites fabricated by a powder metallurgy method. Acta Biomaterialia 4(6): 1944-1952.

Ning, C.Q. \& Zhou, Y. 2004. On the microstructure of biocomposites sintered from Ti, HA and bioactive glass. Biomaterials 25(17): 3379-3387.

Prasad, S., Vyas, V.K., Ershad, M.D. \& Pyare, P. 2017. Crystallization and mechanical properties of (45s5-HA) biocomposite for biomedical implantation. CeramicsSilikáty 61(4): 378-384.

Santhosh, S. \& Prabu, S.B. 2013. Nano hydroxyapatitepolysulfone coating on Ti-6Al-4V substrate by electrospinning. International Journal of Materials Research 104(12): 1254-1262.

Shahrjerdi, A., Mustapha, F., Bayat, M., Sapuan, S.M. \& Majid, D.L.A. 2011. Fabrication of functionally graded hydroxyapatite-titanium by applying optimal sintering procedure and powder metallurgy. International Journal of Physical Sciences 6(9): 2258-2267.

Srivastava, A.K., Pyare, R. \& Singh, S.P. 2012. In vitro bioactivity and physical-mechanical properties of $\mathrm{MnO}_{2}$ substituted 45S5 bioactive glasses and glass-ceramics. Journal of Biomaterials and Tissue Engineering 2(3): 249258.

Veljović, Dj., Jančić-Hajneman, R., Balać, I., Jokić, B., Putić, S., Petrović, R. \& Janaćković, Dj. 2011. The effect of the shape and size of the pores on the mechanical properties of porous HAP-based bioceramics. Ceramics International 37(2): 471-479.

Vitale-Brovarone, C., Baino, F., Tallia, F., Gervasio, C. \& Verné, E. 2012. Bioactive glass-derived trabecular coating: A smart solution for enhancing osteointegration of prosthetic elements. Journal of Materials Science: Materials in Medicine 23(10): 2369-2380.
Wakily, H., Dabbagh, A., Abdullah, H., Halim, N.F.A. \& Kasim, N.H.A. 2015. Improved thermal and mechanical properties in hydroxyapatite-titanium composites by incorporating silica-coated titanium. Materials Letters 143: 322-325.

Weng, J., Liu, X., Zhang, X. \& Ji, X. 1994. Thermal decomposition of hydroxyapatite structure induced by titanium and its dioxide. Journal of Materials Science Letters 13(3): 159-161.

Zhou, S., Li, Y.B., Wang, Y.Y., Zuo, Y., Gao, S.B., Li, M. \& Zhang, L. 2014. The porous structure and mechanical properties of injection molded HA/PA66 scaffolds. International Polymer Processing 29(4): 454-460.

Mohamed Abdulmunem*, Muralithran G. Kutty, Ali Dabbagh, \& Noor Azlin Binti Yahya

Department of Restorative Dentistry

Faculty of Dentistry

University of Malaya

50603 Kuala Lumpur, Federal Territory

Malaysia

Wan Haliza Binti Abd Majid

Department of Physics

Faculty of Science

University of Malaya

50603 Kuala Lumpur, Federal Territory

Malaysia

Noor Hayaty Abu Kasim

Faculty of Dentistry

Universiti Kebangsaan Malaysia

Jalan Raja Muda Abdul Aziz

50300 Kuala Lumpur, Federal Territory

Malaysia

Hadijah Abdullah

Department of Conservative Dentistry

Dental Faculty

MAHSA University, Saujana Putra

42610 Jenjarom, Selangor Darul Ehsan

Malaysia

*Corresponding author; email: mohamadjasem@yahoo.com

Received: 17 January 2019

Accepted: 23 September 2020 